\title{
REE Geochemistry of ore zones in the Archean auriferous schist belts of the eastern Dharwar Craton, south India
}

\author{
T S GIRITH A R A N* and V R A J A M A N I \\ School of Environmental Sciences, Jawaharlal Nehru University, New Delhi 110067 \\ *Presently at Department of Earth Sciences, Pondicherry University, Pondicherry 605014. \\ e-mail: tsgiridharan@yahoo.com
}

\begin{abstract}
The eastern Dharwar Craton of southern India includes at least three $\sim 2700 \mathrm{Ma}$ supracrustal belts (schist belts) which have mesothermal, quartz-carbonate vein gold mineralization emplaced within the sheared metabasalts. In the Hutti and the Kolar schist belts, the host rocks are amphibolites and the ore veins have been flanked by only a thin zone of biotitic alteration; in the Ramagiri belt, however, the host rocks to the veins have been affected by more extensive but lower temperature alteration by fluids. The rare earth element (REE) geochemistry of the host metabasalts, alteration zones, ore veins and the bulk sulfides separated from the ore veins and the alteration zones suggest that

- the REE chemistry of the immediate host rocks has been modified by fluids which added LREE,

- the REE abundance of the ore veins vary with the amount of host rock fragments included in the veins,

- the sulfides formed during mineralization have significant REE concentration with patterns nearly identical to the ore veins and alteration zones and

- therefore the ore fluids involved in gold mineralization here could be LREE enriched.
\end{abstract}

Because alteration and mineralization involved addition of REE, more LREE compared to HREE, the fluids could be of higher temperature origin. The initial $\mathrm{Nd}$ isotope ratios in the host rocks $\left(\varepsilon_{\mathrm{Nd}}\right.$ calculated at $2700 \mathrm{Ma}$ ) showed a large variation $(+8$ to -4$)$ and a deep crustal source for the fluid REE seems likely. A crustal source for $\mathrm{Pb}$ and $\mathrm{Os}$ in the ore samples of Kolar belt has previously been suggested (Krogstad et al 1995; Walker et al 1989). Such a source for ore fluids is consistent with a late Archean (2500Ma) accretionary origin for the terrains of the eastern Dharwar Craton.

\section{Introduction}

Fluids are amongst the most effective agents for the transport of material in the Earth's crust and possibly in the upper mantle. Aqueous hydrothermal fluids are responsible for the formation of many ore deposits and they play a major role in many metamorphic reactions and magmatic processes. Modern exploration strategies should therefore require a thorough knowledge of metalbearing fluids which migrate at different levels in the crust, the possible source(s) of the ore fluids and an understanding of the chemical evolution of the fluid. The origin of the fluids that gave rise to Archean mesothermal gold deposits is contentious, and models utilizing isotope systemat- ics, geochemical and petrological constraints propose either metamorphic (Kerrich and Fryer 1979; Crawford 1981; Groves et al 1987; Phillips and Powell 1993) or magmatic (Burrows et al 1986; Cameron and Hattori 1987) origin for the fluids in these deposits. Compositionally the fluids are reported to be of low salinity $(<2$ wt $\% \mathrm{NaCl}$ equivalent) $\mathrm{H}_{2} \mathrm{O}-\mathrm{CO}_{2}$ fluids with a near neutral or weakly alkaline $\mathrm{pH}$ and normally reducing (Phillips et al 1986 ; Phillips and Powell 1992), although oxidized fluids (Cameron and Hattori 1987; Cameron 1988) have been recorded.

The source of hydrothermal fluids that gave rise to the Archean lode-gold mineralization has been a topic of debate with ore geochemists the world over suggesting fluids that are either internal or

Keywords. REE geochemistry, Archean, lode gold deposit, eastern Dharwar Craton

Proc. Indian Acad. Sci. (Earth Planet. Sci.), 110, No. 2, June 2001, pp. 143-159

(C) Printed in India. 
external to the greenstone belts. Barnicoat et al (1991) studied the mesothermal lode gold deposits of western Australia. The oxygen isotope data on ore samples indicated to them that the fluid composition was strongly controlled by the wallrocks traversed. Therefore these authors suggested that it might be difficult to identify the fluid source for gold deposits. Cameron (1988) attributed the Archean lode gold mineralization to the granulitization process which occurred during the principal period of crustal thickening and stabilization circa $2.7 \pm 0.2 \mathrm{Ga}$ and suggested that upward streaming of mantle $\mathrm{CO}_{2}$ along shear zones in the lower crust led to the dehydration of amphibolite grade rocks to form granulite and this process was accompanied by LILE depletion at higher crustal levels. But, Kerrich (1989) did not support the granulitization process as a likely candidate responsible for Archean lode gold deposits. On the basis of variable $\mathrm{Pb}, \mathrm{C}$, and $\mathrm{O}$ isotope systematics, Kerrich (1989) suggested equilibration of internally or externally derived fluids with compositionally variable crust at low water/rock ratios in transpressive accretionary regimes. Mikucky and Ridley (1993) reviewed the information available on the ore fluid compositions for a wide range of metamorphic conditions from sub-greenschist to lower granulite facies. Based on the alteration zone assemblages and fluid inclusion data, these authors suggested an ore fluid composition that is consistent with derivation from or final equilibration with rocks of intermediate - granitic composition. These authors suggested that the Archean lode-gold mineralization involved either a single fluid moving through the middle and upper crust, or derivation of ore fluids by similar processes at different crustal levels. Ho et al (1992), based on the stable and radiogenic isotope data, suggested a multiple source for the ore fluids in the Archean lode gold deposits of western Australia.

Schandl et al (1995) have studied the REE geochemistry of hydrothermal alteration in the Volcanogenic Massive Sulfide (VMS) deposits of the Superior Province of Canada, and their study revealed that the host felsic volcanics have undergone extensive LREE depletion and hence can be used as an exploration tool for VMS deposits around the Manitouwadge mining camp. Fleet et al (1997) studied the REE geochemistry of the Hemlo gold deposit and their studies indicated that the REE geochemistry remains dominated by the protolith composition and thus cannot be used as a primary tool of exploration. Thus a study of mobility and transport of REE's in the Archean precious metal deposits and the VMS deposits wherein the base metals occur is important in understanding the nature of the hydrothermal fluid responsible for min- eralization in these two types of hydrothermal deposits.

The main objective of this article is to elucidate the nature of hydrothermal fluid and the probable source of the ore fluid in the auriferous schist belts of Hutti, Ramagiri and Kolar in the eastern part of the south Indian Dharwar craton with special emphasis on the REE geochemical data on the ore materials from these belts.

\section{Regional geology of the Dharwar craton}

The cratonic block of south India commonly known as the Dharwar craton, covers an area of $2,38,000 \mathrm{~km}^{2}$ lying between latitudes $12^{\circ} 0^{\prime}$ and $18^{\circ} 0^{\prime}$ and longitudes $74^{\circ} 0^{\prime}$ and $80^{\circ} 0^{\prime}$ (figure 1 ). The cratonic block has been divided into two parts on the basis of a central N-S trending belt of late kinematic plutonic granitoid rocks known as the Closepet Granite. The present study is confined to the lode-gold deposits in the three major auriferous schist belts at Hutti, Ramagiri, and Kolar in the eastern subblock of the Dharwar craton, occurring to the east of the central Closepet Granite. All the three belts consist dominantly of mafic metavolcanic rocks of predominantly tholeiitic composition, except in Kolar where subordinate amounts of komatiitic rocks occur (Rajamani et al 1985, 1989). These belts also include subordinate amounts of felsic metavolcanic rocks and banded iron formations (BIF). Only the Ramagiri schist belt has a few mappable units of serpentinite which probably represent the obducted pieces of Archean oceanic lithosphere (Zachariah et al 1996).

The metavolcanic rocks of the schist belts are $\sim 2700 \mathrm{Ma}$ and are surrounded by $2700-2500 \mathrm{Ma}$ granitic gneisses with a record of distinct geological histories (Balakrishnan et al 1999). The contact between the schist belts and the gneisses are commonly tectonic. However, in the Hutti and Ramagiri schist belts, an intrusive relation between a late phase granite and the supracrustal rocks is seen. The entire eastern subblock of Dharwar craton is thought to have been an accreted terrane and the schist belts represent terrane boundaries. The assembly of the different terranes and their final collision with the western subblock nucleus were thought to have occurred at $\sim 2500 \mathrm{Ma}$ (Krogstad et al 1989; Balakrishnan et al 1999). The geological setting of these three auriferous belts are described in the following paragraphs.

\subsection{Geology of the auriferous schist belts}

\subsubsection{Hutti Schist Belt}

The Hutti Schist Belt is one of the northernmost auriferous schist belts in the eastern Dharwar cra- 

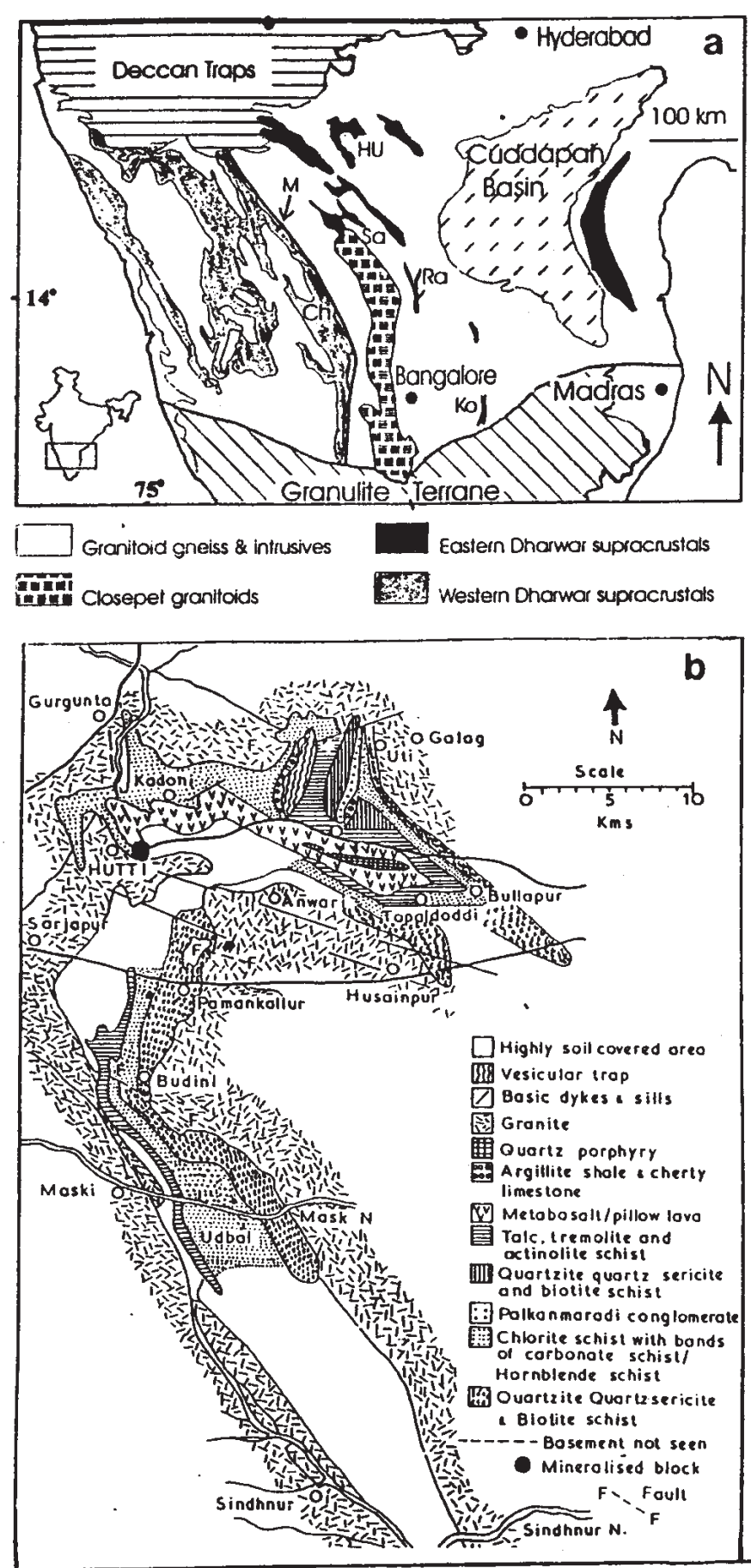
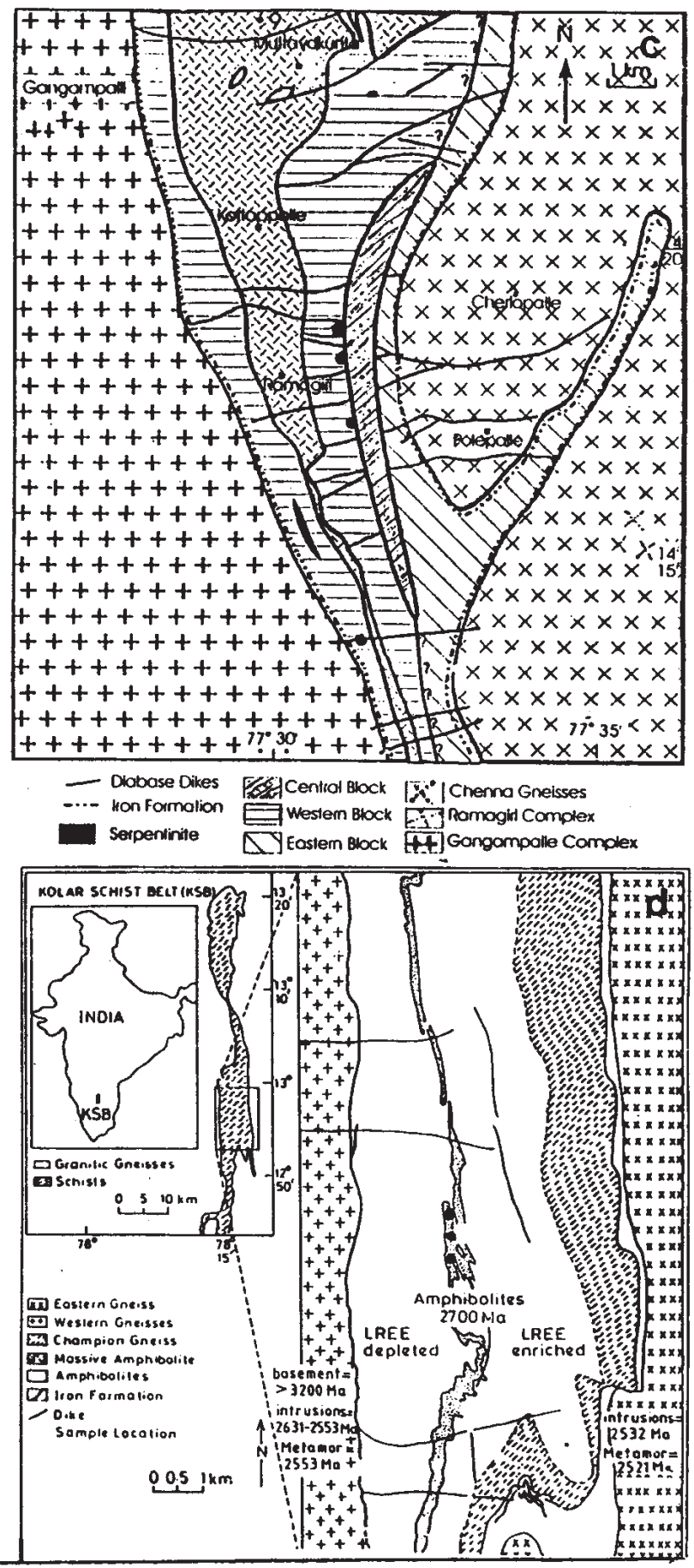

Figure 1. (a). Geological map of southern India. Dharwar Craton is bound by Deccan Traps, Granulite Terrane and Cuddapah Basin. The eastern and western parts of the Dharwar Craton are considered to have had distinct evolutionary histories. $\mathbf{R a}=$ Ramagiri, $\mathbf{K o}=$ Kolar, $\mathbf{S a}=$ Sandur, $\mathbf{H u}=$ Hutti and $\mathbf{C h}=$ Chitradurga schist belts. $\mathbf{M}=$ mylonitized zone on eastern margin of the Chitradurga schist belt. Inset shows location of the Dharwar Craton. (b). Geological map of the Hutti-Maski schist belt (redrawn after Biswas et al 1985). (c). Geological map of the Ramagiri schist belt $\mathrm{U}-\mathrm{Pb}$ ages of Zircons from felsic volcanics from the central block, Chenna Gneiss, Ramagiri and Gangam Complexes are $2707 \pm 18,2650 \pm 7,2613 \pm 6$ and $2528 \pm 1 \mathrm{Ma}$, respectively. (d). Geological map of the Kolar schist belt. In all the three belts, the mineralized areas are indicated by filled-circles. 
ton located $80 \mathrm{kms}$ west of Raichur town. It is a hook shaped schist belt $\sim 65 \mathrm{kms}$ in length and $\sim 8 \mathrm{kms}$ in width consisting predominantly of metavolcanic rocks and subordinate metasedimentary rocks. Pillow-bearing tholeiitic metabasalts dominate the volcanic suite followed by acid volcanics. The belt is surrounded by granitoid rocks which show intrusive relationship at places such as Madriankota and Uti in the northern part. Available whole rock- $\mathrm{K}$ feldspar $\mathrm{Pb}-\mathrm{Pb}$ isochron data for a granite phase suggest an age of $\sim 2600 \mathrm{Ma}$ (Krogstad, unpublished data). The last phase of igneous activity in the Hutti belt is represented by dykes of pegmatite, dolerite and gabbro (Biswas et al 1985). Structural studies by Roy (1979), revealed the presence of three phases of deformation $\left(F_{1}, F_{2}\right.$ and $\left.F_{3}\right)$ in the Hutti belt. Riazullah et al (1996) studied the mineral assemblages and their chemistry in the metabasalts and suggested a metamorphic grade transitional between greenschist and amphibolite facies. Giritharan and Rajamani (1998) studied the geochemistry of the host tholeiitic metavolcanics in the Hutti belt and suggested their derivation from melt-metasomatized mantle sources by different extents of partial melting probably in an island arc tectonic setting.

The gold-quartz-carbonate-sulphide mineralization in the Hutti belt is hosted predominantly by the metabasalts, which is confined to narrow but laterally and vertically persistent tabular bodies in the NNW-trending shear zones. The auriferous lodes of the Hutti belt consist largely of altered wallrock with quartz and carbonate in the form of veins, veinlets and stringers impregnated with sulfide minerals, native gold and scheelite. Apart from native gold in the quartz vein, gold also occurs as inclusions within the sulphide minerals such as arsenopyrite, pyrite and pyrrhotite within the altered wallrocks enveloping the quartz veins (Raju 1996).

\subsubsection{Ramagiri schist belt}

The Ramagiri schist belt is one of the important gold producers in the eastern Dharwar craton located in the Anantapur district of Andhra Pradesh. It is a volcanics dominated trident shaped late Archean schist belt about $50 \mathrm{kms}$ in length and about $3 \mathrm{kms}$ in width at the central part where the present gold mining activity is concentrated. The schist belt consists of two major arms (western and central) and a minor impersistant eastern arm. Detailed geochemical and geochronological information of the Ramagiri schist belt are available in Zachariah et al 1995, 1997. Gold mineralization in the Ramagiri belt occurs in a zone of chlorite-carbonate-quartz-sericite phyllites within the western subblock amphibolites along with minor sulfide minerals such as pyrite and chalcopyrite. Quartz - Carbonate veinlets are localized within the extremely altered (retrogressed) broad phyllitic zones within the amphibolites. Rao et al (1989) reported anomalously abundant native gold and scheelite in association with quartz veins in sericite-chlorite phyllites.

\subsubsection{Geology of the Kolar schist belt}

This is the southernmost N-S trending belt and till recently the most productive auriferous schist belt in the Dharwar craton consisting predominantly of tholeiitic amphibolites. Komatiitic amphibolites, BIF, graphitic schists and felsic schists commonly known as the Champion Gneiss are the other rock types that occur in minor amounts. In the central part of the belt where there is extensive gold mineralization (Kolar Gold Fields) a massive, finegrained, tholeiitic amphibolite unit occurs about which the belt is divided into an eastern part and western part. The central zone where goldquartz vein mineralization is intense appears to be a tectonic contact zone between the two suites of metavolcanics. Krogstad et al (1989) based on a detailed geological, geochemical and geochronological study suggested that the Kolar schist belt is a late Archean suture $(\sim 2500 \mathrm{Ma})$, representing the boundary between at least two distinct late Archean gneissic terranes and that the inferred tectonic setting for the Kolar area is analogous to that proposed for the Mesozoic-Cenozoic margin of the north American Cordillera where faultbounded allochthonous terranes apparently were accreted by plate convergence.

The Kolar belt includes two distinct types of gold mineralization; an amphibolite-hosted quartzcarbonate veins type (Archean lode gold) which is economically the most important and a BIF-hosted stratiform sulfide type. The lode gold mineralization occurs in the central part of the belt as several parallel sets of veins within the shear zones in the eastern LREE enriched tholeiitic amphibolites. A detailed study on geology, geochemistry and isotopic systematics of the stratiform sulfide type by Siva Siddaiah and Rajamani (1989) and Siva Siddaiah et al (1994) revealed a syngenetic volcanic exhalative origin for these deposits and are distinctly different from those of epigenetic vein quartz deposits.

Samples of ore veins from the four main Reefs viz., the Oakley's Reef, Middle Reef, Zone-I Reef and Strike Reef in the underground mine at Hutti and wallrock alteration zone immediately adjacent to the ore veins in the first three Reefs and unaltered host rock at a distance of 5-6 metres on either side of the fourth Reef were collected for geochemical and petrographic studies. In the Ramagiri 
Table 1. Salient features of gold deposits in the three schist belts of the eastern Dharwar craton.

\begin{tabular}{|c|c|c|c|}
\hline & Kolar schist belt & Ramagiri schist belt & Hutti schist belt \\
\hline Host rock & $\begin{array}{l}\text { LREE enriched amphi- } \\
\text { bolites and felsic schists } \\
\text { known as the Champion } \\
\text { Gneiss. }\end{array}$ & $\begin{array}{l}\text { LREE depleted to } \\
\text { flat metabasalts repre- } \\
\text { sented by amphibolites. }\end{array}$ & $\begin{array}{l}\text { Slightly LREE enriched } \\
\text { to flat tholeiitic amphi- } \\
\text { bolites. }\end{array}$ \\
\hline $\begin{array}{l}\text { Wallrock } \\
\text { alteration }\end{array}$ & $\begin{array}{l}\text { Narrow zones of intense } \\
\text { alteration with biotiti- } \\
\text { zation, albitization, sul- } \\
\text { fidation and carbonati- } \\
\text { zation. }\end{array}$ & $\begin{array}{l}\text { A wider zone }(\sim 200 \\
\text { mts }) \text { of not so intense } \\
\text { alteration with sericiti- } \\
\text { zation, saussuritization, } \\
\text { carbonatization and } \\
\text { sulfidation of the host } \\
\text { rock. }\end{array}$ & $\begin{array}{l}\text { Narrow zones of intense } \\
\text { alteration with biotiti- } \\
\text { zation, albitization, car- } \\
\text { bonatization and sulfi- } \\
\text { dation of the host schis- } \\
\text { tose amphibolite. }\end{array}$ \\
\hline Ore vein & $\begin{array}{l}\text { Epigenetic Au-quartz } \\
\text { carbonate vein with } \\
\text { varying amounts of } \\
\text { host rock fragments } \\
\text { and minor sulfides. }\end{array}$ & $\begin{array}{l}\text { A broad zone of } \\
\text { chlorite-carbonate phyl- } \\
\text { lites with sericitization } \\
\text { and sulfidation. }\end{array}$ & $\begin{array}{l}\text { Epigenetic } \mathrm{Au} \text { - quartz- } \\
\text { carbonate veins with } \\
\text { varying amounts of } \\
\text { host rock fragments } \\
\text { and minor sulfides. }\end{array}$ \\
\hline $\begin{array}{l}\text { Mode of } \\
\text { occurrence }\end{array}$ & $\begin{array}{l}\text { Fracture filled veins } \\
\text { with disseminations of } \\
\text { sulfides; gold occurring } \\
\text { in native form in the } \\
\text { quartz vein within the } \\
\text { shear zones. }\end{array}$ & $\begin{array}{l}\text { Fracture filling veins } \\
\text { in the host actinolite- } \\
\text { chlorite schists with } \\
\text { minor sulfides. Gold } \\
\text { occurs as free milling } \\
\text { type within quartz vein } \\
\text { and as inclusions in } \\
\text { sulfides. }\end{array}$ & $\begin{array}{l}\text { Fracture filling veins } \\
\text { in the host amphibo- } \\
\text { lite with minor sulfides. } \\
\text { Gold occurs as both free } \\
\text { milling gold in quartz } \\
\text { and as inclusions in sul- } \\
\text { fides. }\end{array}$ \\
\hline Sulfides & $\begin{array}{l}\text { Pyrrhotite } \pm \text { pyrite } \pm \\
\text { arsenopyrite. }\end{array}$ & $\begin{array}{l}\text { Dominantly pyrite } \pm \\
\text { chalcopyrite. }\end{array}$ & $\begin{array}{l}\text { Dominantly arsenopy- } \\
\text { rite } \pm \text { pyrite } \pm \text { pyrr- } \\
\text { hotite. }\end{array}$ \\
\hline
\end{tabular}

belt diamond drill core samples from the western block of the central arm of Ramagiri belt which includes samples from ore horizons, wallrock alteration zones and unaltered host rocks along with a few samples of host rock from the surface outcrops were collected for geochemical and petrographic studies. In the case of Kolar schist belt, the information available in Siva Siddaiah et al (1990) is used for comparison with the data of Hutti and Ramagiri belts. The details of the nature of host rock, wallrock alteration zone and ore vein in these three auriferous schist belts of eastern Dharwar craton are described below and summarised in table 1.

\subsection{Host rocks}

The unaltered host mafic metavolcanics in the auriferous schist belts are represented by different textural varieties of amphibolites viz., (1) the coarse grained spotted variety, (2) medium grained schistose variety and (3) the fine grained massive variety, all of them having a similar geochemical and mineralogical composition. Mineralization is hosted by the schistose amphibolites which are Fe-rich tholeiite in composition and are characterized by flat to LREE enriched rare earth patterns. Major and trace element modeling of the host tholeiitic metavolcanics from the Hutti schist belt as well as in the Kolar and Ramagiri belts suggests that they were formed from melt enriched mantle sources by different extents of partial melting at pressures $\sim 25$ kbars (Rajamani et al 1989). A critical analysis of the host metavolcanics from all the three belts indicated that the process of formation of Fe-rich tholeiites, their metamorphism to amphibolites and their emplacement along terrane boundaries have provided a favourable geochemical environment for gold mineralization in these three belts. The textural features of the host tholeiitic metavolcanics indicate that they have been subjected to different episodes of shearing, the final one being relatively more brittle.

\subsubsection{Ore veins}

The ore vein in these three belts is a dilational feature in the country rock metabasalts, consisting predominantly of quartz, varying amounts of country rock fragments and minor amounts of carbonates and sulfides (table 1 ). The ore vein generally runs either parallel to the schistosity of the metabasalts or cutting the dominant foliation in the country rock at small angles. In the Kolar and Hutti schist belts, the contacts of the ore vein with the host rock is commonly sharp excepting for a thin, a few centimeter thick, bleached and biotitized wallrock alteration zone, and only in 
the Ramagiri schist belt, the contact of the ore vein with the host is somewhat gradational characterised by a wider wallrock alteration zone.

\subsubsection{Wallrock alteration}

As stated above, the wallrock alteration zone in the auriferous schist belts of Hutti and Kolar are similar and are characterized by a thin zone of bleached country rocks which have undergone biotitization, carbonatization, albitization and sulfidation of the host metatholeiites due to addition of $\mathrm{Na}, \mathrm{K}, \mathrm{CO}_{2}$, $\mathrm{S}$ and $\mathrm{H}_{2} \mathrm{O}$. The thickness of this zone in these two schist belts varies from less than a centimeter to about a meter and is inferred to be dependent on the fluid/rock ratio apart from other factors such as permeability and composition of protoliths and physicochemical conditions of fluids. The lesser the thickness of this wallrock alteration zone, the higher is the intensity of alteration which means a stronger focusing of the ore bearing fluid (high water : rock ratio locally). In both Kolar (Champion Reef) and Hutti (Zone-I Reef) belts such zones are associated with higher gold tenor (personal communication from mine geologists). In the case of Ramagiri schist belt, the elements added to the host rocks are similar to those at Kolar and Hutti belts indicating the involvement of fluids of similar composition but the minerals precipitated from the hydrothermal fluids are different which can be attributed to the relatively lower temperature of the fluid. In the Ramagiri belt, the potassic alteration is represented by the formation of sericite, instead of biotite which is a higher temperature phase and is common in the Kolar and Hutti belts. Moreover, the sulfidation in Ramagiri is represented by the formation of abundant pyrite which has a larger stability field in the system FeAs-S compared to phases such as pyrrhotite and arsenopyrite which are restricted mainly to higher temperatures.

\section{Analytical methodology}

Finely powdered (-200 mesh) and homogenised host rock samples, ore veins and wallrock alteration zone samples from the Hutti schist belt and the diamond drill core samples comprising host metatholeiites, ore zone and wallrock alteration zone from the western block of the central arm of Ramagiri schist belt were analysed for major and trace elements following a modified digestion procedure of Shapiro and Brannock (1962) using $\mathrm{HF}, \mathrm{HNO}_{3}$, and $\mathrm{HClO}_{4}$ and analysed by a Labtam 8440 ICP-AES. $\mathrm{SiO}_{2}$ was determined using a Spectronic -20 Bausch \& Lomb spectrophotometer. Rare earth elements on these samples along with the bulk sulfide separates from the ore veins and wallrock alteration zone in the Hutti and Ramagiri belts were determined by a polychromator in the Labtam 8440 ICP - AES. Standardization for majority of the major and trace elements (excluding REE) were based on USGS rock standards STM-1, RGM-1, W-2 and DNC-1 and in-house rock standards developed at JNU from the samples of Kolar schist belt. For REE determination on the bulk ore veins, wallrock alteration and unaltered host rocks, the procedure given in Giritharan and Rajamani (1998) was followed. Bulk sulfides from the ore veins and wallrock alteration zone samples were handpicked, finely powdered and used for REE determination. 1-2 g of this finely powdered bulk sulfide samples were dissolved initially in 10-20 ml of $6 \mathrm{~N} \mathrm{HNO}_{3}$ and then with concentrated acid, and the solution was allowed to evaporate on a hot plate. It was observed that few undissolved particles were present at the bottom of the teflon beakers used for drying and their examination under a binocular microscope revealed that they were made up mainly of quartz and few amphibole grains and did not have any accessory minerals such as zircon, sphene etc. which would otherwise have an impact on the nature and abundances of REE patterns. This undissolved material was weighed and used for calculating the final abundances of REE in the sulfides. The dried residue of the bulk sulfide samples were then dissolved in $25-30 \mathrm{ml}$ of $1 \mathrm{~N} \mathrm{HCl}$ and loaded on to the $\mathrm{HCl}$ quartz columns packed with the same cation exchange resin (AG50W-X8), since iron is the only major matrix element to be removed. The loaded solution was eluted with $60 \mathrm{ml}$ of $1.7 \mathrm{~N} \mathrm{HCl}$ and the REEs were collected with $240 \mathrm{ml}$ of $6 \mathrm{~N} \mathrm{HCl}$ and dried. The column separation procedure was repeated 2-3 times till all the iron was removed and a colourless final cut obtained. Standardization for REEs was done with metal standards obtained from Johnson Mathey Inc and in-house rock standards (a basalt and a monzodiorite) which were analysed by isotope dilution method at S.U.N.Y., Stony Brook, USA. Calibration of the cation exchange resin columns for the complete recovery of REEs were done by mixing pure metal standards with other major cations and the abundances of these elements in the eluted solution in every $10 \mathrm{ml}$ intervals were determined by ICP-AES. Except for a higher Er value which is due to $\mathrm{Zr}$ interference for this $\mathrm{Er}$ line $(326.478 \mathrm{~nm})$, the values of all other rare earth elements were comparable to that obtained by the isotope dilution method. The precision of our REE analysis is better than $5 \%$ for HREE and better than $10 \%$ for LREE, for basaltic rocks with about $10-20 \mathrm{x}$ chondrite abundance for LREE. 


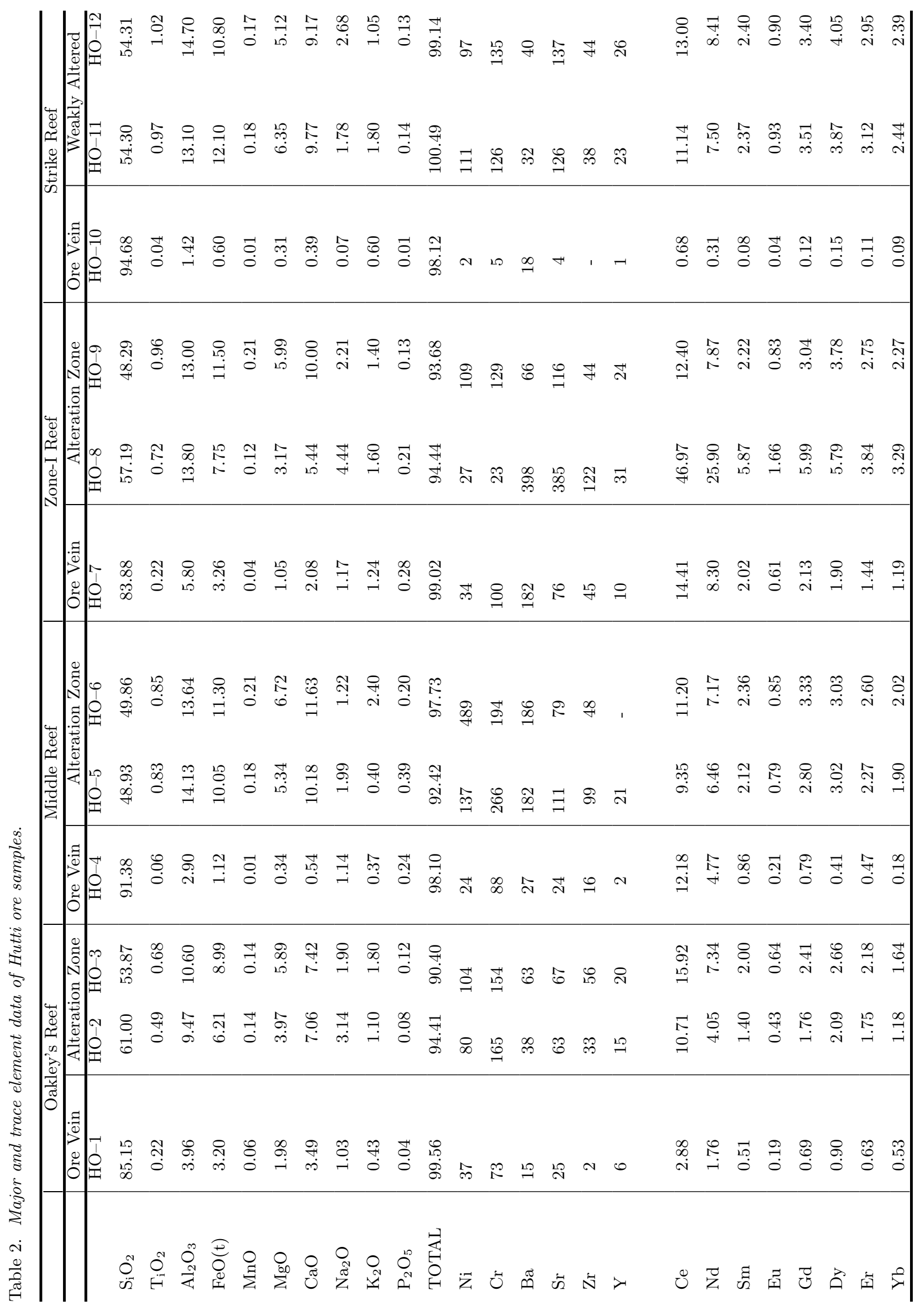




\section{Results}

\subsection{Hutti schist belt}

The major and trace element data including rare earth element data of samples of host rock, wallrock alteration zone and ore veins collected from the underground mine at Hutti is given in table. 2. In Hutti as well as in the other two schist belts ore zone samples studied come from a single lithology, metabasalts, possibly with some differences in their metamorphic history. The binary plot of least mobile major elements such as $\mathrm{Al}_{2} \mathrm{O}_{3}$ and $\mathrm{TiO}_{2}$ (figure 2a) of the Hutti ore samples shows a positive correlation suggesting that (a) $\mathrm{Al}$ and $\mathrm{Ti}$ remained immobile during hydrothermal alteration as suggested by MacLean and Kranidiotis (1987) and that (b) the ore samples can be characterized by two end member composition, the metabasalts and the major ore vein mineral quartz (figure $2 \mathrm{~b}$ and $\mathrm{c}$ ). The variation seen in $\mathrm{Fe}, \mathrm{Mg}$ and $\mathrm{Ca}$ can also be explained by the two end members to a large extent. Because of carbonate addition, the behaviour of $\mathrm{Ca}$ is less regular compared to $\mathrm{Fe}$ and $\mathrm{Mg}$. Similarly $\mathrm{K}_{2} \mathrm{O}$ shows a large non-systematic variation because of varying extents of alteration of amphibole to biotite.

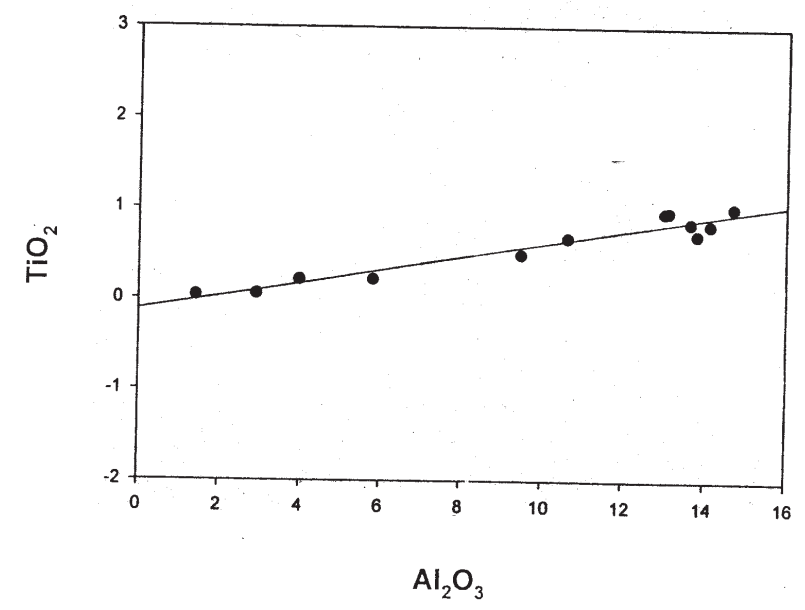

Figure 2(a). Binary plot of $\mathrm{TiO}_{2}$ vs $\mathrm{Al}_{2} \mathrm{O}_{3}$ in the Hutti ore samples.

The variation observed in the trace elements of Hutti ore samples is much irregular compared to the major elements. $\mathrm{Zr}, \mathrm{Cr}, \mathrm{Ni}$ and $\mathrm{Ce}$ show increasingly irregular variation when plotted against Ti. Interestingly the sample with the highest degree of biotitic alteration such as sample \#8 from the Zone-I Reef, seemed to have lost $\mathrm{Ni}$ and $\mathrm{Cr}$, but gained $\mathrm{Ba}, \mathrm{Sr}, \mathrm{Zr}$ and $\mathrm{Y}$.

The rare earth elements (REE) in the Hutti ore samples as a group behaved more irregularly than those of the other trace elements as well as major
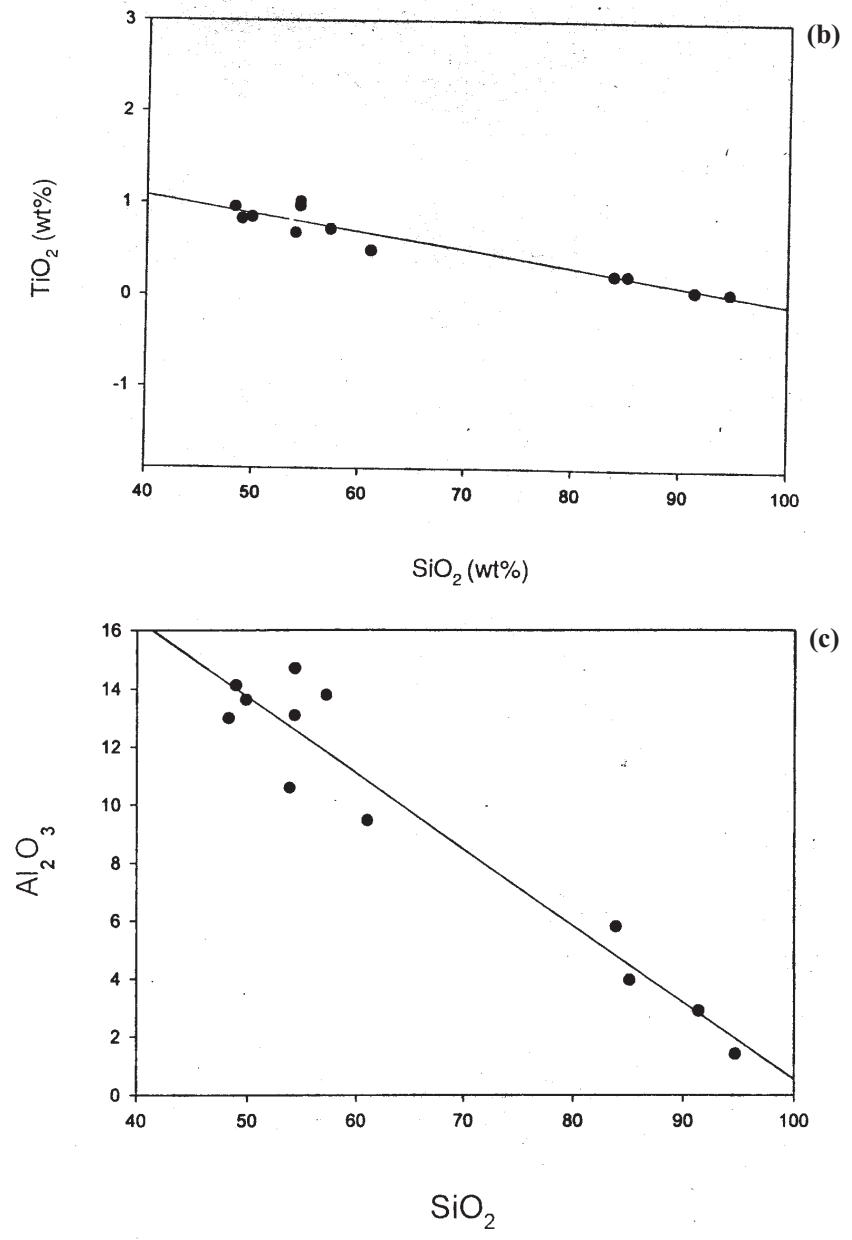

Figure 2(b). Binary plot of (b) $\mathrm{TiO}_{2}$ vs $\mathrm{SiO}_{2}$ of Hutti ore samples, and (c). $\mathrm{Al}_{2} \mathrm{O}_{3}$ vs $\mathrm{SiO}_{2}$ plot of Hutti ore samples.

elements. In the unaltered host amphibolites, the REE patterns are slightly LREE enriched to flat patterns and the abundances vary between $10 \mathrm{x}$ and $20 \mathrm{x}$ relative to chondrite. Among the samples from the wallrock alteration zone those with least alteration in terms of biotitization and carbonatization have REE patterns and abundances very similar to that of the host amphibolite. In sample (\# 8) which has been extensively biotitized, the REE pattern became more fractionated with the abundance of light rare earths increasing to a greater extent than the heavy rare earths. In the present situation, wallrock alteration involved addition of rare earth elements to the metabasalts and the LREEs seem to have been added more than the heavy rare earths.

The ore vein samples show a large variation in terms of rare earth abundance and patterns. This is because of at least two observed factors such as (i) relative proportion of quartz vein and rock fragments and (ii) the intensity of alteration of the included rock fragments. The ore samples associated with the intensely altered wallrock (compare 

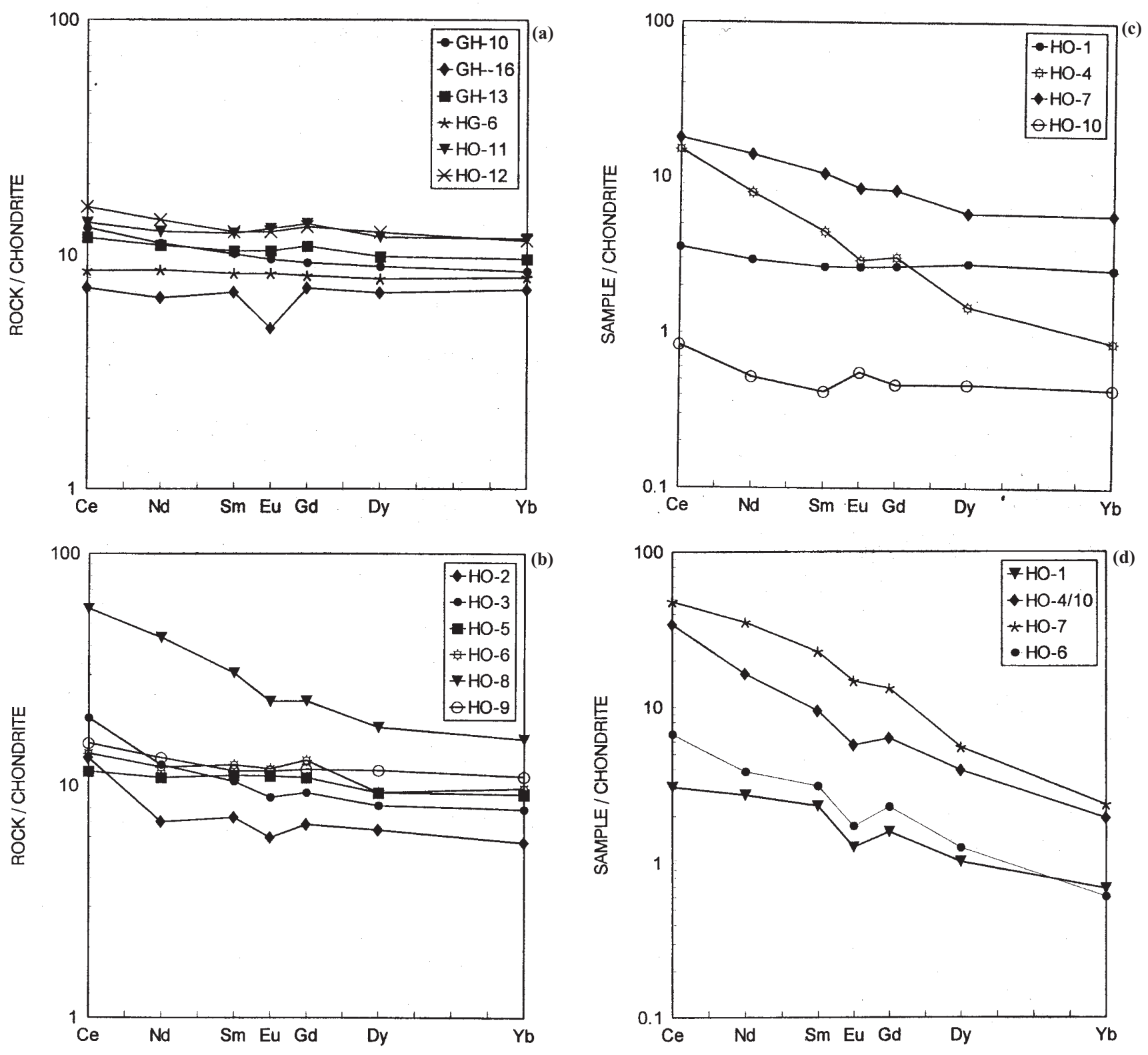

Figure 3. Chondrite normalized REE patterns of Hutti samples. (a) Host rocks (b) Wallrock alteration zone samples (c) Ore veins and (d) Bulk sulfide separates from the ore veins and wallrock alteration zone.

samples No. 8 and 7 in figures $3 \mathrm{~b}$ and c) show similar REE patterns. However the vein sample (No. 7) has much lower REE abundances than the wallrock alteration zone sample (No. 8). Ore vein sample \#4 with a very high abundance of silica in it also has a pattern with LREE enrichment. These observations suggest that the alteration and ore vein formation resulted in a change in the REE patterns, particularly through addition of light rare earths (figure 3d). It appears that the fluids responsible for alteration of the wallrock and precipitation of quartz, carbonate and sulfides were enriched in LREE relative to HREE. This inference is further corroborated by the REE chemistry of the sulfide separates from the ore samples.
The sulfides show LREE enriched and HREE fractionated patterns with different extents of negative $\mathrm{Eu}$ anomaly. The sulfide separates from those ore veins which are associated with relatively higher degrees of alteration, have greater abundances of REE (sample \#4 and \#7 in figure 3e). The ore sample with the least amount of rock fragments (\#4) and the sulfide separated from them have parallel REE patterns with sulfides having relatively higher amounts of REE than the ore vein. In ore samples with higher proportions of included country rock fragments the parallelism between the ore veins and the sulfide separated from them is absent (for example \#7) and the ore vein has higher abundances of HREE relative to the sul- 


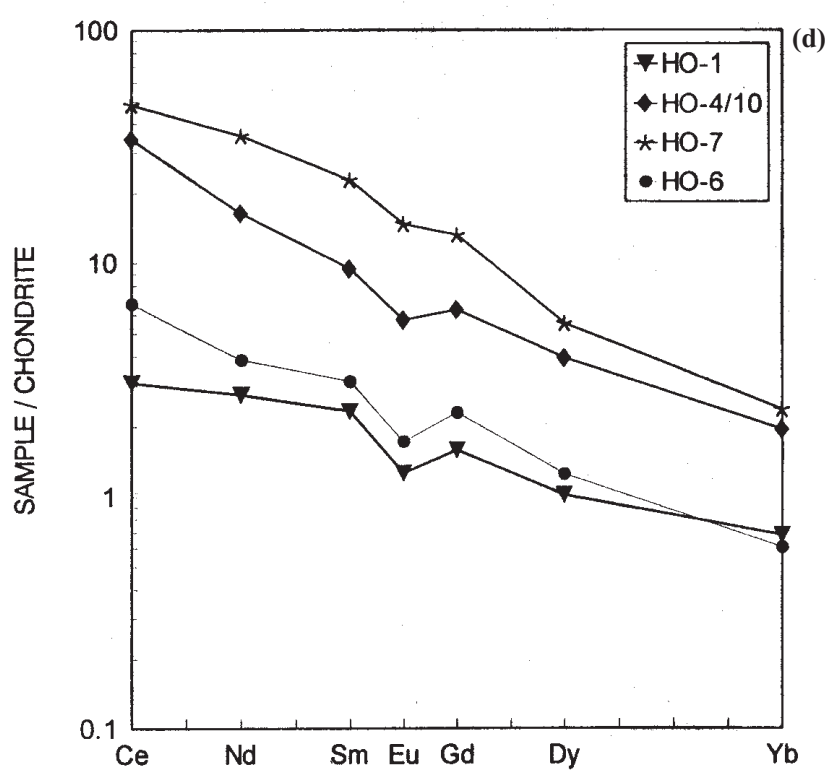

Figure 3. (e) Typical host lithology normalized REE patterns of ore samples from the Hutti belt.

fides because of the presence of amphibole rich rock fragments in the ore vein. Even here, sulfides are significantly enriched in LREE relative to the bulk ore sample.

The similarity of the REE patterns of the bulk sulfide separates from all the ore samples suggests that the sulfide REE patterns could be reasonable proxies to those of the fluids from which the sulfides were precipitated. Although we do not have much information on the selective uptake of REE from ore solutions, available data suggest that sulfides do not fractionate REE (Siva Siddaiah et al 1994). Also we observe that sulfides to some extent determine the REE abundance of the ore samples as well as the alteration samples. These observations are quite different from those reported from the Hemlo deposit (Fleet et al 1997) where hydrothermal alteration of the protoliths resulted in the depletion of REE in general, and greater depletion of LREEs in particular. The secondary minerals added to the ore samples such as quartz, pyrite, barite and carbonates resulted in the dilution of REE contents. Obviously the nature of the fluids involved in the two geological settings could be different. In the present case, if the sulfides provided only active surfaces for the REE as complexes to be adsorbed, then there probably was no fractionation of the rare earths. Siva Siddaiah et al (1994) studied the REE geochemistry of the whole ore and sulfide separates from the BIF hosted Mallappakonda gold sulfide deposit and their study indicated a lack of fractionation of REE by the mineralising fluids. Graf (1977) also suggested that chemical precipitation processes do not commonly fractionate the REE to any signifi- cant extent. In the absence of significant evidence for the fractionation of REE by the fluids, the sulfide rare earth patterns could be a good proxy for the REE patterns of the fluids. The abundances in the sulfides could of course be determined by the (i) temperature of the fluids (ii) the amount of sulfide precipitated and (iii) the grain size of the sulfide minerals precipitated. If in case, sulfides provided suitable structural position for the rare earths, the abundance would also depend on the distribution coefficient between the sulfides and the fluids $\left(K_{d}^{\text {mineral/fluid }}\right)$.

Although we have not analysed the samples for gold, from the available ore grade information, the gold tenor of the ore zones depends on the intensity of alteration. The ore samples from the Zone - I Reef, \#7 and \#8 represent the highest intensity of alteration with the highest abundance of rare earths in them. This reef is known to have the highest grade of ore in the Hutti mine (personal information from mine geologists).

\subsection{Ramagiri schist belt}

Drill core samples representing unaltered host rock, wallrock alteration and ore zone were collected from the Ramagiri schist belt and were analysed for major and trace elements including REE (table 3). In this auriferous belt also, the ore samples belong to a single lithology, metabasalt, as at Hutti. However, the host metabasalts in this belt are metamorphosed only up to upper greenshist facies as evidenced by the mineral assemblage with ubiquitous presence of chlorite. The fluid alteration in the Ramagiri schist belt is represented by a wider zone of ( $\sim 200$ metres) less intense, lower temperature alteration and this is exemplified by a virtually undisturbed major element chemistry of the ore samples. The ore horizon in this belt is a broader zone of chloritic, sericitic and carbonate alteration with minor sulfidation within the massive metabasalts and the contact between the ore samples and unaltered host is gradational. The ore samples in this auriferous belt cannot be characterised by two end member compositions in a binary plot of immobile major elements such as $\mathrm{Al}$ and $\mathrm{Ti}$ as in the case of Hutti schist belt although in this binary plot (figure $4 \mathrm{a}$ and $\mathrm{b}$ ) the Ramagiri ore samples show a linear array suggesting that both these elements remained relatively immobile as at Hutti. $\mathrm{Fe}, \mathrm{Mg}$ and $\mathrm{Ca}$ when plotted against $\mathrm{TiO}_{2}$ also show a somewhat linear arrangement of sample points but are less regular compared to similar plots of Hutti ore samples. Trace elements such as $\mathrm{Ni}, \mathrm{Cr}$, and $\mathrm{Ba}$ show little or no correlation when plotted against $\mathrm{TiO}_{2}$.

The wallrock alteration zone in the western block of the Ramagiri schist belt is characterized by acti- 


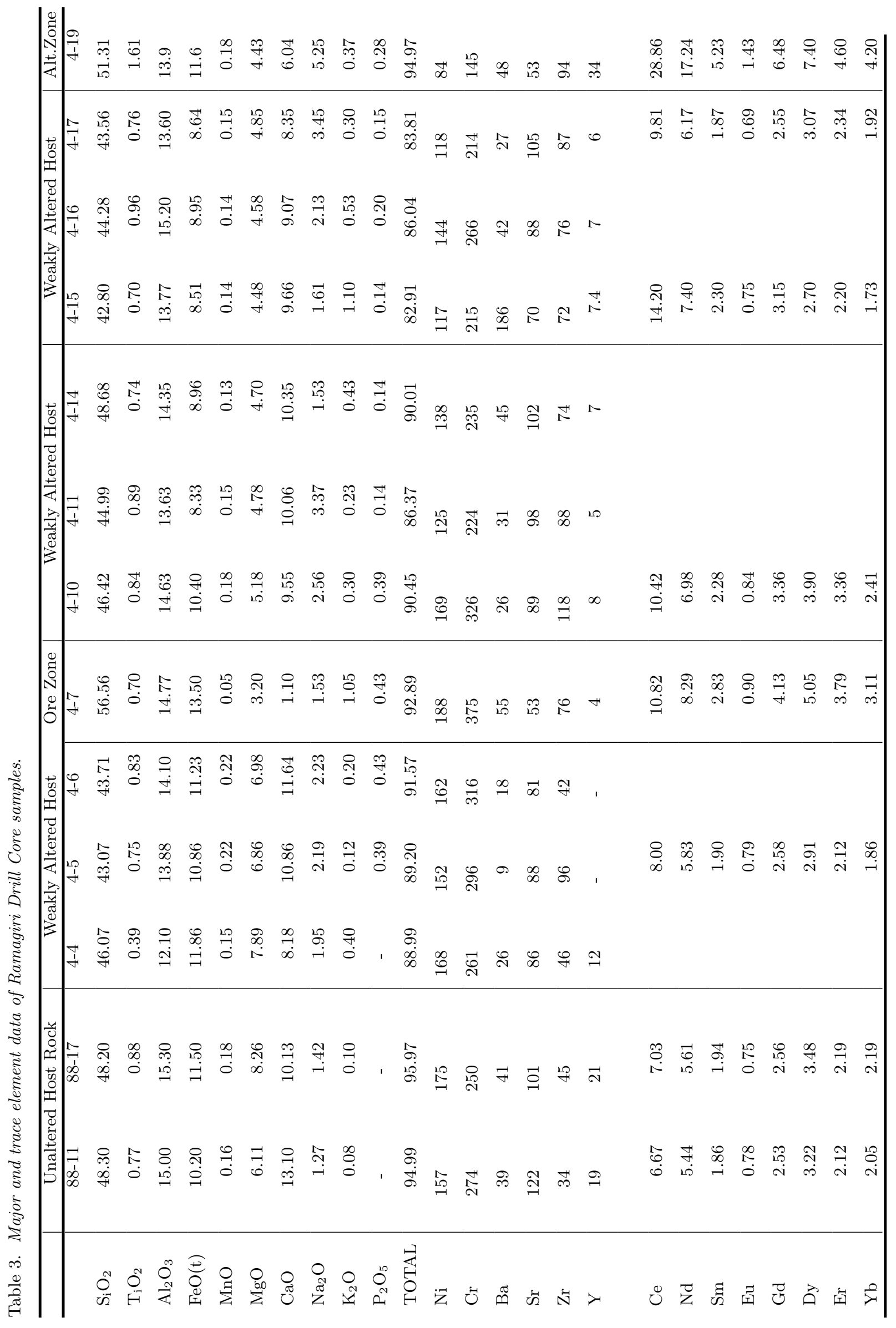


Table 4. REE data of bulk sulfide separates from the ore veins and wallrock alteration zone in the Hutti and Ramagiri schist belts.

\begin{tabular}{cccccc}
\hline & HO-1 & HO-4/10 & HO-7 & HO-6 & $4-19$ \\
\hline $\mathrm{Ce}$ & 2.495 & 27.806 & 39.273 & 5.450 & 4.104 \\
$\mathrm{Nd}$ & 1.631 & 9.753 & 21.175 & 2.301 & 1.450 \\
$\mathrm{Sm}$ & 0.446 & 1.811 & 4.370 & 0.598 & 0.424 \\
$\mathrm{Eu}$ & 0.091 & 0.411 & 1.057 & 0.124 & 0.136 \\
$\mathrm{Gd}$ & 0.411 & 1.635 & 3.412 & 0.595 & 0.540 \\
$\mathrm{Dy}$ & 0.331 & 1.277 & 1.795 & 0.407 & 0.570 \\
$\mathrm{Er}$ & 0.193 & 0.610 & 0.696 & 0.210 & 0.524 \\
$\mathrm{Yb}$ & 0.142 & 0.404 & 0.492 & 0.126 & 0.380 \\
\hline
\end{tabular}
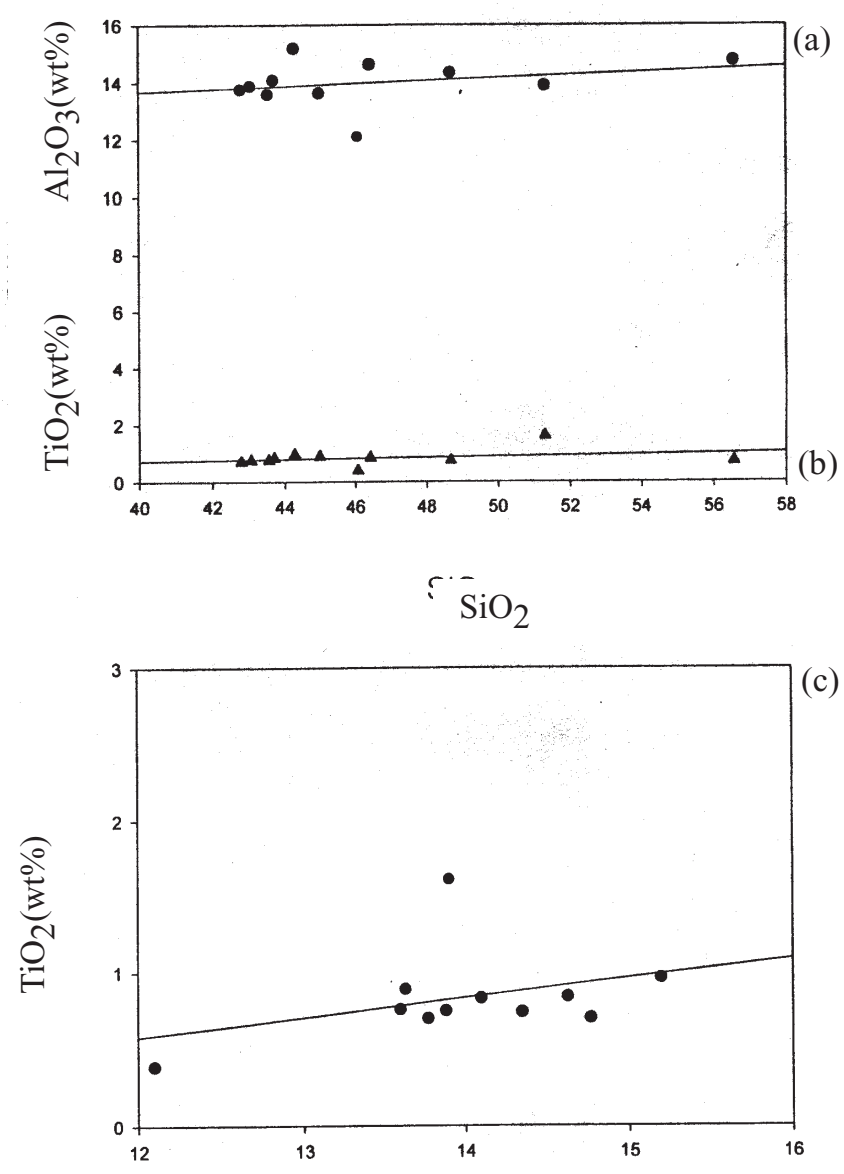

$\mathrm{Al}_{2} \mathrm{O}_{3}(\mathrm{wt} \%)$

Figure 4. Binary plot of Ramagiri ore samples showing (a) $\mathrm{SiO}_{2}$ vs $\mathrm{Al}_{2} \mathrm{O}_{3}$, (b) $\mathrm{SiO}_{2}$ vs $\mathrm{TiO}_{2}$ and (c) $\mathrm{Al}_{2} \mathrm{O}_{3}$ vs $\mathrm{TiO}_{2}$.

nolite \pm chlorite \pm albite \pm calcite \pm sericite \pm quartz with minor sulfides which include mainly pyrite. Typical wallrock alteration zone (\#4-19) in the Ramagiri belt is characterised by higher contents of $\mathrm{Si}, \mathrm{Ti}, \mathrm{Na}, \mathrm{K}, \mathrm{Ba}, \mathrm{Sr}$ and $\mathrm{Zr}$ and lower concentrations of $\mathrm{Ca}, \mathrm{Fe}, \mathrm{Ni}$ and $\mathrm{Cr}$ than the unaltered host rock. The sample studied shows a similarity to the wallrock alteration zone of the Hutti belt. Ore sample \# 4-7 has the highest silica (56. 6 wt \% only) and $\mathrm{Ni}, \mathrm{Cr}$ contents among the drill core samples studied but this sample has the lowest $\mathrm{CaO}$ content and is characterised by silicification and sericitization of the host lithology. Wallrock sample \# 4-15 which has undergone sericitization, has the highest $\mathrm{K}_{2} \mathrm{O}$ and $\mathrm{Ba}$, Sr contents and is moderately enriched in REE.

The chondrite normalised REE patterns obtained on the unaltered host rock, alteration zone and ore zone drill core samples of the western block is shown in the figures 5 a to $5 \mathrm{~d}$. The REE as well as other trace elements in Ramagiri ore samples behaved more regularly than those of the Hutti ore samples indicating that the fluid alteration did not affect the chemistry significantly. In the unaltered host lithology from the western block of the central arm of the Ramagiri belt the REE pattern is slightly LREE depleted $\left(\mathrm{Ce}_{\mathrm{N}} / \mathrm{Yb}_{\mathrm{N}}=0.7\right)$ to flat pattern. The wallrock alteration samples (\# 4-19 and \# 4-15) on the other hand have slightly LREE enriched $\left(\mathrm{Ce}_{\mathrm{N}} / \mathrm{Yb}_{\mathrm{N}}=1.76\right)$ and slightly fractionated HREE patterns $\left(\mathrm{Gd}_{\mathrm{N}} / \mathrm{Yb}_{\mathrm{N}}=1.23\right.$, figure 5b), but with a higher REE abundance than the unaltered host rocks. Just as in the Hutti schist belt, here also the fluid alteration has resulted in the addition of REE, more so of LREE than HREE. As at Hutti, the alteration related REE addition is highly variable.

The bulk sulfides separated from the wallrock alteration sample \# 4-19 in the Ramagiri belt have a lower abundance of REE than the host sample \# 4-19, but has a more pronounced LREE enrichment and a slightly fractionated HREE pattern (figure 5d). This has similarity to the bulk sulfide pattern from the wallrock alteration of Hutti belt (\# HO-6) in terms of LREE enriched nature but the HREE fractionation is more in the bulk sulfides from the wallrock in Hutti belt than in the Ramagiri belt.

Apart from the addition of rare earths by hydrothermal fluid alteration, albitization of the wallrock also appears to be a characteristic feature of both these auriferous belts. 

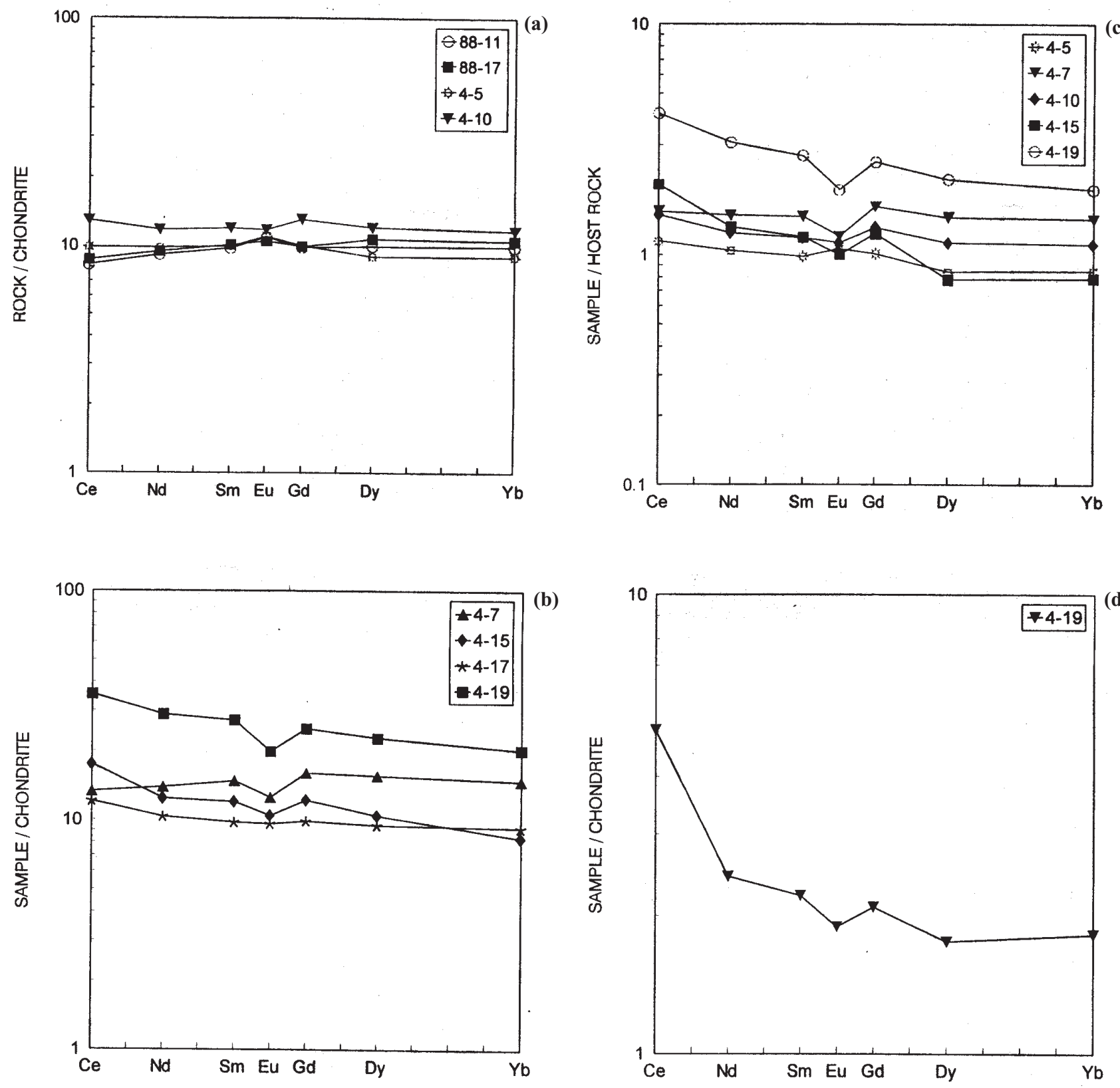

Figure 5. Chondrite normalized REE patterns of Ramagiri samples. (a) Host rock, (b) Wallrock alteration and ore zone, (c) Typical host rock normalized REE pattern of Ramagiri ore samples, (d) Bulk sulfide separates from wallrock.

\subsection{Fluid alteration in the Kolar schist belt}

Sajid (1987) studied the chemistry of wallrock alteration samples associated with the gold-quartzcarbonate veins from the Oriental and McTaggart lodes in the Kolar mine. A comparison of the same with the unaltered host metatholeiites collected from surface outcrops indicated that the chemistry of wallrock samples does not differ significantly from that of the unaltered host amphibolites. This study also revealed the absence of any systematic change in the chemistry of wallrock between the contact zones and the one away from it barring small scale changes in the chemistry in a thin zone (few cms) of bleached wallrock adjacent to the ore vein. This zone is characterised by extensive biotitization and the biotite seems to have resulted from reactions involving diopside, hornblende, titanite and K- bearing fluids (Siva Siddaiah et al 1990).

Siva Siddaiah et al (1990) characterised the REE chemistry of the ore veins, wallrock alteration zone and unaltered host amphibolites in the Kolar schist belt (figure 6). These authors reported that the ore veins in this belt are characterised by variable abundances of REEs but similar LREE enriched and HREE fractionated patterns. The abundances of REE in the ore vein samples vary at least by two orders of magnitude and appears to be controlled 


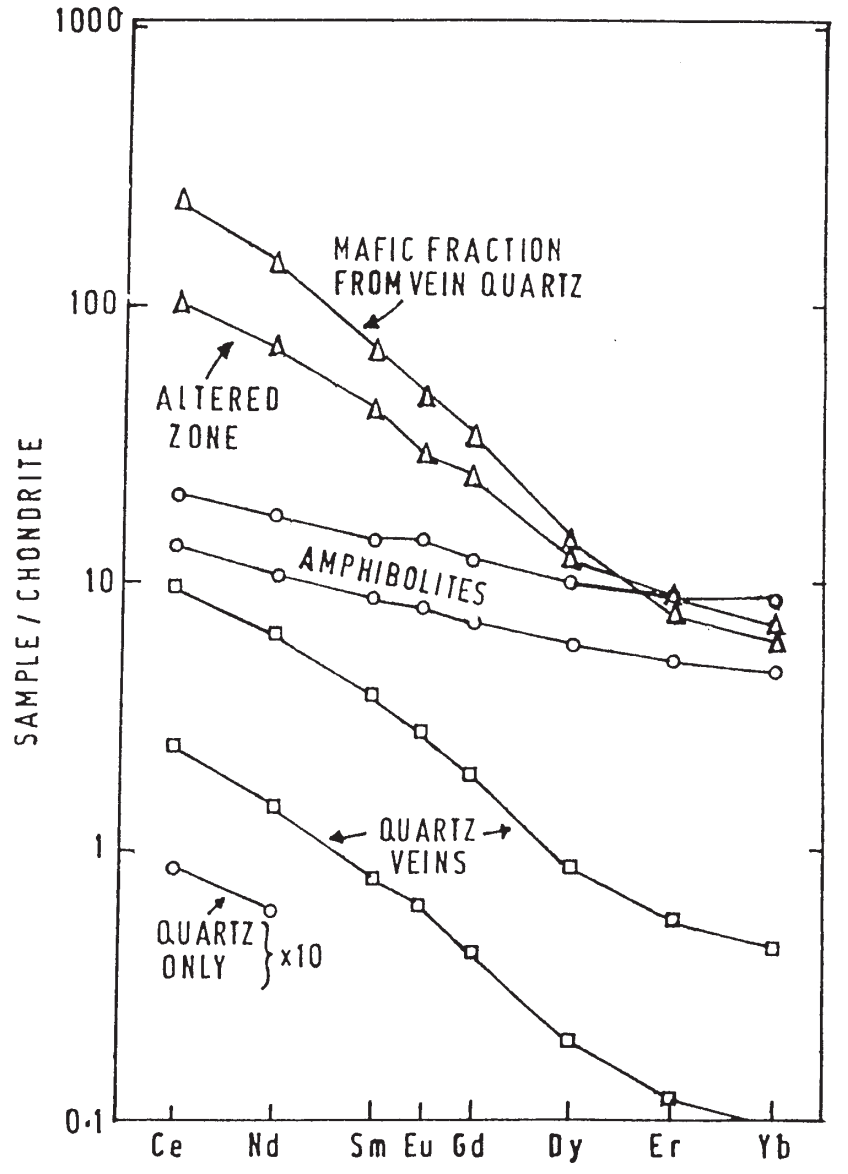

Figure 6. REE patterns of host amphibolites, wallrock alteration zone, ore veins and mafic fraction from ore veins in the Kolar schist belt (after Siva Siddaiah et al (1990a)).

by the proportion of rock fragments in the veins, as seen in the Hutti ores. Samples rich in fragments of amphibolite have higher abundances of REE. The wallrock alteration zones adjacent to the ore vein in the Kolar belt have patterns that are similar to the ore veins but dissimilar to the host rock REE pattern indicating that the REE chemistry of the immediate host has been modified by the fluids. REE, more so LREE, have been added to the wallrock just as seen in the Hutti ores. Thus in the Kolar belt, the fluid has imposed it's signature on the immediate host rock, indicating a higher fluid /rock ratio at least locally within the shear zone. The metamorphic grade of the host rock and alteration zone mineralogy are similar to that of the Hutti belt and are indicative of high temperature of the fluids. The only notable difference between the two schist belts (Hutti and Kolar) arises from the sulfide mineralogy of the ore vein and wallrock alteration zone. The abundant sulfide in the ore veins of the Kolar schist belt is pyrrhotite, whereas that in the Hutti belt is arsenopyrite.

\section{Discussion}

The mobility of a particular group of REE in hydrothermal solutions has been shown to depend on (a) the physicochemical conditions of the host environment, most importantly the temperature, $\mathrm{fO}_{2}$ (b) $\mathrm{pH}$ of the fluid and (c) the water/rock ratio (Michard and Albarede 1986; Shenberger and Barnes 1989; Sanjuan et al 1988 and Michard 1989. Michard and Albarede (1986) showed that the seafloor hydrothermal fluids are preferentially enriched in the lighter REE and $\mathrm{Eu}^{2+}$ and depleted in HREE. These authors concluded that the preexisting REE concentrations in rocks remain relatively unchanged unless the water/rock ratios are very high $\left(>10^{6}\right)$. These authors also suggested that the high temperature fluids can mobilize more of LREE than HREE and the low temperature $\mathrm{CO}_{2}$ rich fluids can mobilize more HREE relative to LREE.

The addition of rare earths by fluids, especially the light rare earths, to the host lithology as seen in the case of auriferous zones of the three schist belts of eastern Dharwar craton can occur only if the fluids were of high temperature and that the fluids were not acidic at the time of interaction with the host rocks. The abundance of REEs in the fluids as indicated by the bulk sulfide REE abundance from the ore zones in the Hutti, Ramagiri and Kolar schist belts and their REE patterns indicate that fluids were not mantle derived $\mathrm{H}_{2} \mathrm{O}-\mathrm{CO}_{2}$ fluids, since such fluids are reported to have very high REE abundance $(\sim 6000 \mathrm{x}$ chondritic abundance of Ce, Hanson 1981). Therefore it is possible that the fluids were $\mathrm{H}_{2} \mathrm{O}$ dominated, crustallyderived fluids probably related to the granulitization of the lower crust, similar to that reported by Cameron (1988).

Although the fluids involved in the Archean lode gold deposits at Hutti, Kolar and Ramagiri of the eastern Dharwar craton are broadly similar, in terms of temperature and source $(\mathrm{s})$ of the ore fluid, there appears to be some localised differences between the Ramagiri belt and the other two belts as indicated by the mineral assemblage in the wallrock alteration zone. The potassic alteration in the Ramagiri belt is manifested in the formation of sericite instead of biotite which is common in the Kolar and Hutti belts and saussuritization of plagioclase is seen only in the Ramagiri belt. As mentioned in the preceding paragraphs this could be due to a relatively lower temperature of the hydrothermal fluid in the Ramagiri belt. The predominance of pyrite in the Ramagiri belt over high temperature sulfide minerals such as pyrrhotite and arsenopyrite which is seen in the Kolar and Hutti belts respectively also supports the idea of a relatively lower temperature of the fluid in the 


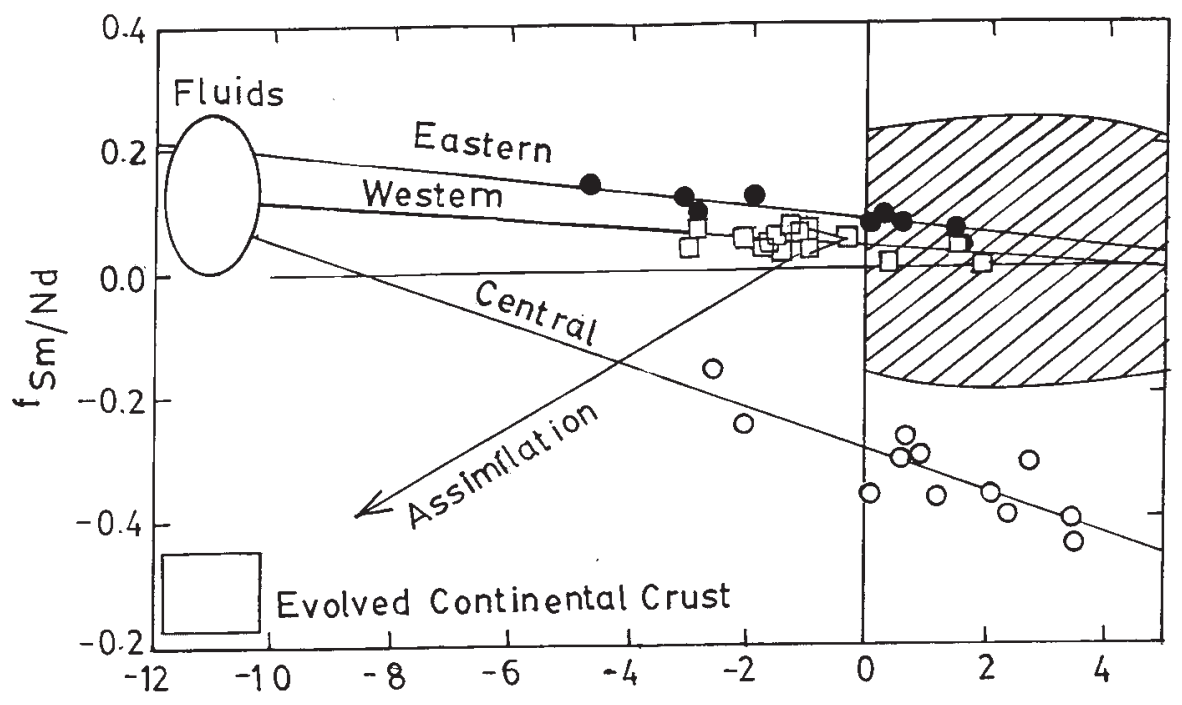

Figure 7. $\quad \mathrm{f}_{\mathrm{Sm} / \mathrm{Nd}}$ vs. $\varepsilon_{\mathrm{Nd}}$ diagram showing host rock amphibolites from the three different blocks of the Ramagiri schist belt. For mantle derived basaltic rocks, negative $\varepsilon_{N d}$ values are anomalous. This and the trends shown by the three suites of rocks indicate that their Nd isotopic systematics were disturbed by interaction with crustally derived fluids (after Zachariah et al 1997b). The hatched area at the right shows the field for Kolar amphibolites.

Ramagiri belt. Zachariah et al (1995) attributed the preservation of distinct $\mathrm{Nd}$ isotope composition in closely spaced samples of metabasalts of Ramagiri schist belt to low temperature fluid interactions. The gold tenor of the Ramagiri ore is less compared to that of Kolar and Hutti belts. It is possible that low grade alteration mineralogy in the ore zones, almost negligible addition of REE and low gold tenor of the ore are related features resulting from low temperature of the ore fluids and/or low fluid/rock ratios. In the Hutti mine also, ore zones with least change in REE have lowest gold tenor.

The REE abundance of typical wallrock alteration zone samples of Hutti and Ramagiri belts when normalized against the REE abundance of unaltered host rock in the respective schist belts also supports the LREE enriched nature of the fluid (figure 3d and figure 5c). The host rock normalized pattern for the Hutti samples is much more fractionated with relatively higher enrichment of LREE relative to Ramagiri samples. This is perhaps a result of localised differences in the temperature of mineralizing fluids in the Hutti and Ramagiri belts. It has been noted earlier that the REE pattern of hydrothermal fluids is to a large extent determined by the temperature of fluids. The host rock normalized pattern of the Ramagiri alteration zone shows a very sharp negative $\mathrm{Eu}$ anomaly. This could be due to the interaction of the fluid with a calcic plagioclase dominated lithology of granodioritic/dioritic composition on its path, which could have resulted in the selective depletion of $\mathrm{Eu}$ relative to other REE.
A detailed study of the $\mathrm{Sm}-\mathrm{Nd}$ isotopic systematics of all varieties metabasalts in the Ramagiri belt indicated a post-magmatic disturbance of the Nd isotopic system (Zachariah et al 1995 and 1997). Because $\epsilon_{\mathrm{Nd}}$ at $2700 \mathrm{Ma}$ showed a large range from +3 to -4 for mantle derived magmas (figure 7), their $\mathrm{Sm}$ - Nd systematics were modelled to suggest interaction of these metabasalts after their emplacement (2700 Ma) but before 2480 Ma with crustally derived fluids $\left(\epsilon_{\mathrm{Nd}} \sim-8\right.$ to -10). Similarly the Kolar amphibolites also showed a large range of $\epsilon_{\mathrm{Nd}}$ at $2700 \mathrm{Ma}$, from +8 to $\sim 0$, which could also possibly be due to interaction with crustally derived fluids (Balakrishnan et al 1990; Zachariah et al 1997).

In the Kolar belt, compelling evidence for the involvement of crustal fluids in ore formation is provided by evolved signatures of Os and $\mathrm{Pb}$ isotopic data for samples of ore zones (Walker et al 1989; Krogstad et al 1995). Pb isotopic data for quartz samples from the ore veins of Ramagiri and Hutti belts, however, are less radiogenic and are similar to the associated metabasalts (Zachariah et al 1997). Thus ore forming hydrothermal fluids must have evolved and / or interacted with older crustal lithologies in addition to the host metabasalts during the late Archean crustal growth.

The eastern Dharwar craton was thought to have formed by accretion and collision of different continental, island arc and oceanic terranes in the time interval between 2510 and 2450Ma (Krogstad et al 1989; Balakrishnan et al 1999). This period of accretion and collision coincides with the granulite formation now occurring at the 
southern and southeastern margins of the craton (Peucat et al 1993a). Although we do not have any age data for the ore veins in the three belts, at Kolar, a 2465Ma pegmatite dyke crosscuts the gold-quartz-carbonate ore veins in the amphibolite. The processes of cratonization, granulite formation and gold mineralization along terrane boundaries are possibly related both temporally and spatially. And in the Dharwar craton of southern India, it seems to have occurred around 2500Ma, unlike in other shield areas where the same events are reported to be somewhat older (Balakrishnan et al 1999).

\section{Summary}

The three gold mineralised schist belts in the eastern Dharwar craton show evidence of varying extents of REE addition, more so LREE, to the host rocks immediately adjacent to the ore veins. The magnitude of REE addition seems to depend on the temperature of alteration as inferred from the alteration zone mineralogy. Sulfide minerals formed from the ore fluids all have LREE enriched REE patterns, variable abundances and negative $\mathrm{Eu}$ anomaly. It is inferred that fluids responsible for gold mineralization could have had LREE enriched REE chemistry resulting from higher temperature source regions. Available initial $\mathrm{Nd}$ isotope data $\left(\epsilon_{\mathrm{Nd}}\right.$ at $\left.2700 \mathrm{Ma}\right)$ for the host amphibolites point to their interaction with crustally derived fluids after their magmatic crystallization. Because the mineralised belts are considered to be terrane boundaries (not greenstone belts), and the ore fluids are likely to be deep-seated with multiple sources, the model of transpressive tectonic regime for gold mineralization seems applicable to these late Archean gold deposits.

\section{Acknowledgements}

This paper forms a part of the Ph.D. dissertation work of T S G during which J.N.U. provided a Research Fellowship. Financial assistance from CSIR in the form of Research Associateship to T S G is gratefully acknowledged. This research was also supported by NSF Grants INT 9322645 to V R and Prof. G. N Hanson of S.U.N.Y., Stony Brook, USA. We thank Dr. R H Sawkar and Dr. K K Raju of the Hutti Gold Mines Limited for the logistic support during the field work and for providing the ore samples from the underground mine at Hutti.

\section{References}

Balakrishnan S, Hanson G N and Rajamani V $1990 \mathrm{~Pb}$ and $\mathrm{Nd}$ isotope constraints on the origin of high $\mathrm{Mg}$ and tholeiitic amphibolites, Kolar Schist Belt, south India; Contributions to Mineralogy and Petrology, 107 279-292

Balakrishnan S, Rajamani V and Hanson G N 1999 U$\mathrm{Pb}$ ages for Zircon and titanite from the Ramagiri area, southern India: Evidence for accretionary origin of eastern Dharwar craton during Late Archean; J. Geol. (in press).

Barnicoat A C, Fare R J, Groves D I and McNaughton N J 1991 Synmetamorphic lode-gold deposits in high-grade Archean settings; Geology, 19 921-924

Biswas S K, Prabhakaran K and Rao, P S 1985 Preliminary exploration of auriferous lodes of Hutti - Maski schist belt, Karnataka, India. U.N. Regional seminar on gold exploration and development, Bangalore. Section II, $1-29$

Burrows D R, Wood P C and Spooner E T C 1986 Carbon isotopic evidence for a magmatic origin for Archean goldquartz vein ore deposits; Nature 321 851-854

Cameron E M and Hattori K 1987 Archean Gold Mineralization and Oxidized Hydrothermal fluids; Economic Geology 82 1177- 1191

Cameron E M 1988 Archean gold: Relation to granulite formation and redox zoning in the crust; Geology 16109 112

Crawford M L 1981 Fluid inclusions in metamorphic rocks - low and medium grade. In short course on fluid inclusions: Applications to petrology (eds). L S Hollister and M L Crawford Mineralogical Association of Canada, 6 $157-181$

Fleet M E, Seller M H and Pan Y 1997 Rare Earth Elements, Protoliths and Alteration at the Hemlo Gold deposit, Ontario, Canada, and comparison with Argillic and sericitic alteration in the Highland Valley Porphyry District, British Columbia, Canada; Economic Geology 92 551-568

Giritharan T S and Rajamani V 1998 Geochemistry of the metavolcanics of the Hutti - Maski Schist Belt: Implications to gold metallogeny in the eastern Dharwar craton; J. Geol. Soc. India 51 583-594

Graf J L 1977 Rare earth elements as hydrothermal tracers during the formation of massive sulfide deposits in volcanic rocks; Econ. Geol 72 527-548

Groves D I, Phillips G N, Ho S E, Houston S M and Standing C A 1987 Craton scale distribution of Archean greenstone gold deposits: predictive capacity of the metamorphic model; Economic Geology 82 2045-2058

Hanson 1981 Geochemical constraints on the evolution of the early continental crust; Philosophical Transactions of the Royal Society, London A 301423 - 442

Kerrich R and Fryer B J 1979 Archean precious metal hydrothermal systems, Dome mine, Abitibi greenstone belt. II. REE and oxygen isotope relations; Canadian Journal of Earth Science 16 440-458

Kerrich R and Fryer B J 1981 The separation of rare elements from abundant base metals in Archean lode gold deposits: Implications for low water / rock source regions; Economic Geology 76 160-166

Kerrich R 1989 Archean Gold: Relation to granulite formation or felsic intrusions; Geology 17 1011-1015

Kerrich R and Wyman D 1990 Geodynamic setting of mesothermal gold deposits: An association with accretionary tectonic regimes; Geology 18 882-885

Krogstad E J, Balakrishnan S, Mukhopadhyay D K, Rajamani V and Hanson G N 1989 Plate Tectonics. 2.5 billion 
years ago: Evidence at Kolar, South India. A report; Science 243 1337-1340

Krogstad E J, Hanson G N and Rajamani V 1995 Sources of continental magmatism adjacent to the late Archean Kolar Suture Zone, South India : distinct isotopic and elemental signatures of two late Archean magmatic series; Contributions to Mineralogy and Petrology 122 159-173

MacLean W H and Kranidiotis P 1987 Immobile elements as monitors of mass transfer in hydrothermal alteration : Phelps Dodge Massive Sulfide Deposit, Matagami, Quebec; Economic Geology 82 951-962

Michard A 1989 Rare earth element systematics in hydrothermal fluids; Geochimica Cosmochimica Acta $\mathbf{5 3}$ $745-750$

Michard A and Albarede F 1986 The REE content of hydrothermal fluids; Chemical Geology 55 51-60

Mikucky E J and Ridley J R 1993 The hydrothermal fluid of Archean lode-gold deposits at different metamorphic grades: compositional constraints from ore and wallrock alteration assemblages; Mineralium Deposita 28469 481

Peucat J J, Mahabaleswar B and Jayananda M 1993a Age of younger tonalitic magmatism and granulitic metamorphism in the south Indian transition zone (Krishnagiri area); comparison with older Peninsular Gneisses from the Gorur-Hasan area; J.Metamorphic.Geol 11 $879-888$

Phillips G N and Powell R 1993 Link between gold provinces; Economic Geology 1993 1083-1098

Rajamani V, Shivkumar K, Hanson G N and Shirey S B 1985 Geochemistry and petrogenesis of amphibolites, Kolar schist belt, south India: Evidence for Komatiitic magma derived by low percentages of melting of the mantle; J. Petrol. $2692-123$

Rajamani V, Shirey S B and Hanson G N 1989 Fe-rich Archean tholeiites derived from melt enriched mantle sources: Evidence from the Kolar schist belt, south India; J. Geol. $97487-501$

Raju K K 1996 Geology, mineralization and structural controls in Hutti gold deposit. In: Gold 96: National workshop on exploration and exploitation of gold resources of India, NGRI, Hyderabad 71-88

Rao K S P, Sastry R S N, and Raju S V 1989 Scheelite as a prospecting tool for gold in the Ramagiri greenstone belt, Andhra Pradesh, India; Journal of Geochemical Exploration. 31 307-317

Riazullah M S, Pathan A M and Maaskant P 1996 The characterization of metamorphic facies of metabasalts of Hutti greenstone belt; J. Geol. Soc. India 47 547-554

Roy Abhinaba 1979 Polyphase folding deformation in the Hutti - Maski schist belt, Karnataka; J. Geol. Soc. India 20 598-607

Sanjuan B, Michard A and Michard G 1988 Influence of the temperature of $\mathrm{CO}_{2}$-rich springs on their aluminium and rare earth contents; Chemical Geology 68 57-67
Sajid M 1987 Some geochemical aspects of wallrock alteration of the Kolar gold sulfide lodes. Unpublished M.Phil dissertation, Jawaharlal Nehru University, New Delhi, India, $73 \mathrm{p}$.

Schandl E S, Gorton M P and Wasteneys H A 1995 Rare earth element geochemistry of the metamorphosed volcanogenic massive sulfide deposits of the Manitouwadge mining camp, Superior Province, Canada: A potential exploration tool ? Economic Geology 92 1217-1236

Shapiro L and Brannock W W 1962 Rapid chemical analysis of silicate, carbonate and phosphate rocks; US Geol. Surv. Bull. 1144 A 56

Shenberger D M and Barnes H L 1989 Solubility of gold in aqueous sulfide solutions from 150 to $350^{\circ} \mathrm{C}$; Geochim.Cosmochim.Acta 53 269-278

Siva Siddaiah N and Rajamani V 1989: The geologic setting, mineralogy, geochemistry, and genesis of gold deposits of the Archean Kolar Schist Belt, India; Economic Geology $842155-2172$

Siva Siddaiah N, Hanson G N and Rajamani V 1990a REE and isotope studies of gold deposits of the Archean Kolar Schist Belt of the Dharwar craton, south India. In: Third International Archean Symposium, Perth, 1990. Extended Abstracts Volume, (eds) J E Glover and S E Ho pp 367-368

Siva Siddaiah N, Hansen G N and Rajamani V 1994 Rare earth element evidence for syngenetic origin of an Archean stratiform gold sulfide deposit, Kolar Schist Belt, south India; Economic Geology 89 1552-1566

Taylor R P and Fryer B J 1982 Rare earth element geochemistry as an aid to interpreting hydrothermal ore deposits. In: Mineralization associated with acid magmatism (ed) A M Evans (John Wiley \& Sons, Ltd)

Walker R J, Shirey S B, Hanson G N, Rajamani V and Horan M F 1989 Re-Os, Rb-Sr and O isotope systematics of the Archean Kolar Schist Belt, Karnataka, India; Geochimica Cosmochimica. Acta 53 3005-3013

Zachariah J K, Gopalan K, Hemming S R, Siddaiah N S, Giritharan T S, Rajamani V and Hanson G N 1997a $\mathrm{Pb}$ isotope data on gold mineralised quartz veins from three gold deposits of eastern Dharwar craton, south India. Abstract, In: Geological Association of CanadaMinerological Association of Canada Meeting, Ottawa May, 1997.

Zachariah J K, Hanson G N and Rajamani V 1995 Post crystallization disturbances in the $\mathrm{Nd}$ and $\mathrm{Pb}$ isotope systems of metabasalts from the Ramagiri schist belt, south India; Geochimica Cosmochimica Acta 59 3189-3203

Zachariah J K, Mohanta M K and Rajamani V 1996 Accretionary evolution of the Ramagiri schist belt, eastern Dharwar craton; J. Geol. Soc. India 47 279-291

Zachariah J K, Balakrishnan S and Rajamani V 1997b Significance of $\mathrm{Sm}-\mathrm{Nd}$ isotope systematics in crustal genesis: A case study of Archean metabasalts of the eastern Dharwar craton; Proc. Indian Acad. Sci. ( Earth Planet. Sci.) $106361-367$ 